FIU Law Review

Codification, Progressive Development, New Law, Doctrine, and the Work of the International Law Commission on Peremptory Norms of General International Law (Jus Cogens): Personal Reflections of the Special Rapporteur

Dire Tladi

Professor of International Law, University of Pretoria; Member of the UN International LawCommission and its Special Rapporteur on Jus Cogens, diretladi2012@gmail.com

Follow this and additional works at: https://ecollections.law.fiu.edu/lawreview

Part of the International Law Commons

Online ISSN: 2643-7759

Recommended Citation

Dire Tladi, Codification, Progressive Development, New Law, Doctrine, and the Work of the International Law Commission on Peremptory Norms of General International Law (Jus Cogens): Personal Reflections of the Special Rapporteur, 13 FIU L. Rev. 1137 (2019).

DOI: https://dx.doi.org/10.25148/lawrev.13.6.13

This Article is brought to you for free and open access by eCollections. It has been accepted for inclusion in FIU Law Review by an authorized editor of eCollections. For more information, please contact lisdavis@fiu.edu. 


\title{
Codification, Progressive Development, New Law, DOCTRINE, AND THE WORK OF THE INTERNATIONAL LAW COMMISSION ON PEREMPTORY NORMS OF GENERAL InTERnational LaW (Jus Cogens): Personal REFLECTIONS OF THE SPECIAL RAPPORTEUR
}

\author{
Dire Tladi*
}

I. Introduction

II. The Genesis of the Topic Jus Cogens.

III. Jus Cogens in the Work of the Commission

IV. Conclusion 1149

\section{INTRODUCTION}

At the outset, I wish to express my deep gratitude to the FIU Law Review, and our good friend, Professor Charles Jalloh for organizing this fascinating seminar on codification and progressive development of international law in commemoration of the seventieth anniversary of the International Law Commission (the "Commission").

The mandate of the Commission is progressive development and codification-well, technically the mandate of the Commission is "the promotion of progressive development of international law and its codification." Progressive development is said to be "the preparation of draft conventions on subjects which have not yet been regulated by international law or in regard to which the law has not yet been sufficiently developed in the practice of States" while codification refers to "the more precise formulation and systematization of rules of international law in fields where there already has been extensive State practice, precedent and doctrine." ${ }^{2}$ In simple terms the technical meaning of the phrase "progressive development" refers to activities of the Commission when the practice of States in a certain area cannot be said to meet the requirements for customary international law i.e., widespread and consistent practice coupled with opinio juris, while

\footnotetext{
* Professor of International Law, University of Pretoria; Member of the UN International Law Commission and its Special Rapporteur on Jus Cogens. This paper was written during time as Global Visiting of Professor of Law the University of California Irvine on a Fulbright Research Grant.

11947 Statute of the International Law Commission, art 1.

2 Id. at art. 15.
} 
codification refers to those cases where there is widespread practice accepted as law, i.e., customary international law. In a recent article, I described the distinction as follows:

In other words, codification refers to circumstances where the rule in question is lex lata or hard law. Progressive development ... refers to instances where there is some practice but the practice would not, strictly speaking, meet the requirements for customary international law. Rules advanced as progressive development may be 'emerging rules' but they have to have some basis in state practice. ${ }^{3}$

Several caveats should be made. First, whether the Commission is engaged in an exercise of progressive development or codification, its work is always (or should always be) based on the existence of practice. In the case of progressive development, the practice need not be widespread, consistent, or accompanied by opinio juris (acceptance as law), but it should be present. Second, and more importantly, in its practice, with some exceptions, the Commission has not generally identified individual provisions in a given topic as either progressive development or codification. In its practice, the Commission has regarded "the distinction between the two processes as unworkable" and has, rather, proceeded on the basis of a "composite idea of codification and progressive development." "Third, in the context of the topic "immunities of state officials from foreign criminal jurisdiction" some members of the Commission have introduced a third category of the outputs, called, pejoratively, "new law." This category applies, it seems, to those provisions of the Commission's work that have no basis in the practice of law and thus constitutes neither progressive development nor codification. ${ }^{6}$

Against this background, this contribution to the seminar will address the topic of peremptory norms of general international law (jus cogens), for which I serve as Special Rapporteur. I will in this paper address how this

3 Dire Tladi, The International Law Commission's Recent Work on Exceptions to Immunity: Charting the Course for a Brave New World in International Law?, 32 LEIDEN J. INT'L L. 169, 172 (2019); Dire Tladi, The International Law Commission's Draft Articles on the Protection of Persons in the Event of Disasters: Codification, Progressive Development or Creation of Law from Thin Air?, 16 CHINESE J. INT'L L. 425, 426 (2017) [hereinafter Tladi, Draft Articles].

4 United NATIONS, THE WORK OF THE INTERNATIONAL LAW COMMisSiON 47 (8th ed. 2012).

5 See, e.g., Statement by Murphy, U.N. ILC, 69th Sess., Provisional Summary Record of the 3362nd Meeting, U.N. Doc. A/CN.4/SR.3362 (2017); Statement by Wood, U.N. ILC, 69th Sess. Provisional Summary Record of the 3360th Meeting, UN Doc. A/CN.4/SR.3360 (2017).

6 In fairness to these members, although not using the phrase "new law," I myself had described the Commission's work on the topic of "Protection of Persons in the Event of Disasters" as neither codification nor progressive development and had, for that topic, said the Commission had created law "out of thin air." See Tladi, Draft Articles, supra note 3, at 426. 
framework of codification and progressive development - perhaps also "new law"-has influenced my work as Special Rapporteur and the Commission's own approach to the reports of the Special Rapporteur.

In the next section I describe the genesis of the topic. In the context of the topic peremptory norms of general international law (jus cogens), which I will from this point on refer to simply as "the topic jus cogens," the genesis of the topic is of particular importance since one of the key issues in determining whether to place the topic on agenda was the question of existence of practice. I will then, in section 3, discuss the role of practice in the four reports ${ }^{7}$ submitted thus far, including in the responses to the reports by members of the Commission and States. ${ }^{8}$ I will then offer some concluding remarks.

\section{THE GENESIS OF THE TOPIC JUS COGENS}

When I proposed the topic jus cogens I was fully aware of how special the concept was. I knew that I had to approach the topic with a degree of awe because as special concepts in international law go, few can rival jus cogens. To understand the concept of jus cogens and how special it is, it is important to remember that the system of international law is essentially a horizontal one. First, in this horizontal system, the subjects of law make the law themselves, which means they are free, as a rule, to contract out of existing rules of international law. Second, in a properly horizontal system of law, there is no hierarchy and all rules have equal status. Yet jus cogens departs from these essential characteristics of international law in that rules of jus cogens, first, cannot be contracted out of - they are non-derogable-and, second, these norms are hierarchically superior to other rules of international law. This is nothing less than revolutionary! ${ }^{9}$ It is thus not surprising that the word "magic" has so often been associated with the concept of jus cogens. ${ }^{10}$

7 See Dire Tladi (Special Rapporteur), First Rep. on Jus Cogens, U.N. Doc. A/CN.4/693 (Mar. 8, 2016) [hereinafter Tladi, First Report]; Dire Tladi (Special Rapporteur), Second Rep. on Jus Cogens, U.N. Doc. A/CN.4/706 (Mar. 16, 2017) [hereinafter Tladi, Second Report]; Dire Tladi (Special Rapporteur), Third Rep. on Peremptory Norms of General International Law (Jus Cogens), U.N. Doc. A/CN.4/714 (Feb. 12, 2018) [hereinafter Tladi, Third Report]; Dire Tladi (Special Rapporteur), Fourth Rep. on Peremptory Norms of General International Law (Jus Cogens), U.N. Doc. A/CN.4/727 (Jan. 31, 2019) [hereinafter Tladi, Fourth Report].

8 Tladi, Fourth Report, supra note 7, 116.

9 Alain Pellet, Conclusions, in THE Fundamental Rules of the InTERnATIONAL LegaL ORder: Jus COGENS AND OBLIGATIONS ERGa OMNes 417, (Christian Tomuschat \& Jean-Marc Thouvenin eds., 2005) [hereinafter THE FUNDAMENTAL RULES].

10 Andrea Bianchi, Human Rights and the Magic of Jus Cogens, 19 European J. InT'L L. 491 (2008); Dinah Shelton, Sherlock Holmes and the Mystery of Jus Cogens, 46 NETH. Y.B. INT'L L. 23 (2015); see also Anthony D'Amato, It's a Bird, It's a Plane, It's Jus Cogens, 6 ConN. J. INT'L L. 1, 2 
But the full measure of the extraordinary character of jus cogens is perhaps captured in the remarks of Alain Pellet, who observed that the concept of jus cogens shared the same initials (JC) as someone who, a long time ago, turned water into wine. ${ }^{11}$ All of this illustrates just how special jus cogens is.

It is because of this magical, revolutionary and perhaps miraculous quality that when I first proposed the topic, I had fully expected that the Commission would decide not to take up the topic. My intention had then been that, after the rejection by the Commission, I would go off and write a book - without by the way, the constraints of practice. It was thus a surprise when the Commission decided that it would take the topic up. But the decision was, by no means, easy and there were certainly objections raised. The objections were, in many ways, related to the theme of this seminarprogressive development and codification and the role of practice. ${ }^{12}$ One member suggested that, whatever the state of practice, some topics, like jus cogens, should be "above the glass ceiling" and that the Commission should avoid taking on such topics. This concern spoke to the magical, revolutionary or miraculous character of jus cogens. I confess that I also had some trepidation about pursuing this topic; fear that the Commission, a generally conservative body, might do some damage to the evolution of the concepta fear that, as will become apparent, was not far-fetched. A consequence of this "glass ceiling" objection for practice-and the progressive development/codification dichotomy — was that the Commission would have to handle the topic carefully, including by ensuring that its conclusions were backed by practice. In this respect, when talking to my students about the Commission's work on jus cogens I will always remind them about Ian Brownlie's quip that jus cogens was like a car stuck in garage. I tell them that the project of the Commission is an attempt to get the car out of the garage. Yet, as much as you want the car out of the garage, you don't want to be giving the car keys to your sixteen-year-old son to go on a joy-ride, especially if the car is a Bentley, as jus cogens would certainly be if it were a car. So, my intention as Special Rapporteur was to fully ensure that the work done was consistent with practice.

The second objection, which was that shared by several members of the Commission, was that there simply was not sufficient practice to justify taking this topic on. It will be recalled that in its commentary to Draft Article

(1990) ("Indeed, the sheer ephemerality of jus cogens is an asset, enabling any writer to christen any ordinary norm of his or her choice as a new jus cogens norm, thereby in one stroke investing it with magical power.").

11 Alain Pellet, Conclusions, in THE Fundamental RULES, supra note 9, at 217.

12 Since the discussions took place in the context of the Working Group on the Long-Term Programme of Work - a closed meeting - I am not in a position to ascribe the views to specific members of the Commission. 
50 of the 1966 Draft Articles on the Law of Treaties, the Commission made the following observations:

The emergence of rules having the character of jus cogens is comparatively recent, while international law is in the process of rapid development. The Commission considered the right course to be to provide in general terms that a treaty is void if it conflicts with a rule of jus cogens and to leave the full content of the rule to be worked out in State practice and in the jurisprudence of international tribunals. ${ }^{13}$

The argument by members of the Commission that raised the concern about including the topic on the agenda of the Commission was that there had not been sufficient practice in the period since the adoption of the Vienna Convention on the Law of Treaties to justify further study on the topic of jus cogens. This argument was raised by both members of the Commission and States in the General Assembly. Three States in particular raised the concern. France was no surprise, it had been opposed to the concept of jus cogens for sometime and had raised a number of concerns, including the lack of practice. ${ }^{14}$ Spoiler alert: I, as Special Rapporteur, did not consider France as a persistent objector to the doctrine of jus cogens - assuming persistent objection had any role whatsoever to play in relation to jus cogens. This no doubt elicited a strong reaction. ${ }^{15}$ It was equally understandable that the United States, the most powerful State in the world-politically, economically and militarily — would be suspicious of a concept such as a jus cogens since, by definition, jus cogens is intended to restrict power. The US was thus another State to object to jus cogens, and it did so principally from the perspective that there was not sufficient practice to justify its inclusion in the agenda of the Commission. The one surprise was The Netherlands. Its objection to the study jus cogens was the one surprise that, as Special

131966 ILC Draft Articles on the Law of Treaties, 3 of Commentary to Draft art. 50.

14 In describing France's objection to the inclusion of the topic to my students, I have often said it threw everything plus the kitchen sink and hoped that one of missiles would bring the topic down. Another issue that France raised was, whatever the merits of the topic, the Commission's agenda was too full, and the inclusion of a new topic would overburden the Commission.

15 See Tladi, Second Report, supra note 7, at 17 ("It is true, as France noted, that the practice of France was of particular interest to the Special Rapporteur. This was because France was known as having objected to the very idea of jus cogens. Yet actual practice, as seen from the statements of France itself, shows this to be inaccurate. The assessment was not concerned with whether France is or is not a persistent objector and nowhere does the first report draw any conclusions in this respect. All that the report states, with regard to France, is the well-documented fact that, at the adoption of the Vienna Convention, France did not object to the idea of jus cogens. Rather, France expressed concern about the lack of clarity concerning how it would be applied and the possibility for its abuse."). 
Rapporteur, I did not foresee. The Dutch objection to taking up the topic was also based on the lack of practice.

A third objection, not related to practice and referred to here only for completeness sake, was that an illustrative list of jus cogens-the final element proposed for study-would be too difficult and the Commission would never reach agreement. ${ }^{16}$

\section{JUS COGENS IN THE WORK OF THE COMMISSION}

It is perhaps useful to begin with the first report of the Special Rapporteur and the Commission's consideration of that report. As Special Rapporteur, my intention with the first report was to get a soft landing. The first report therefore focused on what I perceived to be non-controversial issues, with support in both practice and doctrine. The first report therefore provided an immemorable historical description of the emergence of jus cogens and a description of what was commonly accepted as the definition and characteristics of jus cogens. It was meant to facilitate a kumbaya spirit within the Commission before the heavy lifting of the second and third report began-boy, was that perception misplaced!

The first report proposed three draft conclusions which, in my view as Special Rapporteur and law professor, were relatively uncontroversial. The first draft conclusion, a scope provision, simply provided what this topic concerned. This was indeed uncontroversial. The second draft conclusion sought to explain the general structure of international law as a horizontal legal system where most rules were jus dispositivum, which could be contracted out of. The provision would then spell out that this general rule was subject to the exception that was jus cogens. This draft conclusion was based on a large quantity of international judicial practice. ${ }^{17}$ There was also

16 The member of the Commission that held this view famously said drawing up a list "could be done either in five minutes or it would take fifty years."

17 North Sea Continental Shelf Cases (Ger. v. Den.; Ger. v. Neth.), Judgment, 1969 I.C.J. 3, 72 (Feb. 1969) ("Without attempting to enter into, still less pronounce upon any question of jus cogens, it is well understood that, in practice, rules of international law can, by agreement, be derogated from in particular cases, or as between particular parties."). For a more explicit recognition of the distinction between jus cogens and jus dispositivum see South West Africa Cases (Eth. v. S. Afr.; Liber. v. S. Afr.), Second Phase, Judgment, 1966 I.C.J. 6, at 298 (July 1966) (dissenting opinion of Tanaka, J.) (“jus cogens, recently examined by the International Law Commission, [is] a kind of imperative law which constitutes the contrast to the jus dispositivum, capable of being changed by way of agreement between States."); Maritime Delimitation in the Area between Greenland and Jan Mayen (Den. v. Nor.), Judgment, 1993 I.C.J. 38, 135 (June 1993) (separate opinion by Shahabuddeen, J.) ("States are entitled by agreement to derogate from rules of international law other than jus cogens."); see Pulp Mills on the River Uruguay (Arg. v. Uru.), Judgment, 2010 I.C.J. 14, 43 (Apr. 2010) (separate opinion of Ad Hoc Torres, J.) (“As the rules laid out in Articles 7 to 12 of the Statute of the River Uruguay are not peremptory norms (jus cogens), 
ample State practice in support of this very basic principle. ${ }^{18}$ This basic principle was also largely accepted in the doctrine. ${ }^{19}$ Yet in that first year (2016), to my utter surprise, only one member supported this basic proposition. ${ }^{20}$ This draft conclusion was therefore dead on arrival.

The real fight, however, was the proposal in the first report that norms of jus cogens were hierarchically superior to other norms, universally applicable, and reflected and protected the fundamental values of the international community. This draft conclusion, to me, almost went without

there is nothing to prevent the Parties from deciding by 'joint agreement."'); Prosecutor v. Kupreškić et al., Case No, IT-95-16-T, Judgment, ๆ 520 (Jan. 14 2000) ("most norms of international humanitarian law, in particular those prohibiting war crimes, crimes against humanity and genocide, are also peremptory norms or jus cogens, i.e. of a non-derogable and overriding character."); Reservations to the Convention on the Prevention and Punishment of the Crime of Genocide, Advisory Opinion, 1951 I.C.J. 15, at 24 (May 1951) ("The object and purpose of the Convention thus limit the freedom of making reservation."); The Oscar Chinn Case (U.K. v. Belg.), Judgment, 1934, P.C.I.J. (Ser. A/B No. 63), at 149 (Dec. 1934) (separate opinion of Schüking, J.) ("And I can hardly believe that the League of Nations would have already embarked on the codification of international law if it were not possible, even to-day, to create a jus cogens, the effect of which would be that, once States have agreed on certain rules of law, and have also given an undertaking that these rules may not be altered by only some of their number, any act adopted in contravention of that undertaking would be automatically void."); Right of Passage over Indian Territories (Port. v. India) Merits, Judgement, 1960 I.C.J. 6 - 29 (Apr. 1960) (dissenting opinion of Fernandes, J.) (“Several rules cogentes prevail over any special rules. And the general principles to which I shall refer later constitute true rules of ius cogens, over which no special practice can prevail.”); Military and Paramilitary Activities in and against Nicaragua (Nicaragua v. United States), Judgment, 1986 I.C.J. 14, at 199 (June 1986) (separate opinion of Sette-Cama, J.); Arbitral Award of 31 July 1989 (GuineaBissau v. Sen.), Judgment, 1991 I.C.J. 53, at 155 (Nov. 1991) (dissenting opinion of Weeramantry, J.) ("[A] treaty which offends against a rule of $j$ us cogens, though complying fully with all the requirements of procedural regularity in its creation, can still be null and void owing to a factor lying outside those procedural formalities.”); Nuclear Tests Case (Austl. v. Fr.), Judgment, 1974 I.C.J. 253 9 389 (Dec. 1974) (dissenting opinion of de Castro, J.) (discussing wherein the jus cogens status of a treaty provision is questioned because of, inter alia, the right to withdraw).

18 See also R.M. v. Attorney General, et al. (2006) 2010 K.L.R. 1, 12 (High Court of Kenya at Nairobi); Siderman de Blake v. Republic of Argentina, 965 F.2d 699, 715-16 (9th Cir. 1992).

19 AleXander OrakhelashVili Peremptory Norms in International LaW 8-9 (2006); Alfred Verdross, Jus Dispositivum and Jus Cogens in International Law, 60 AM. J. INT'L. L. 55, 58 (1966) ("There was clearly consensus in the Commission that the majority of the norms of international law do not have the character of jus cogens."); Christian Tomuschat, The Security Council and Jus Cogens, in The PResent AND Future of JUS Cogens 19 (Enzo Cannizzaro ed., 2015) ("Most of the rules of international law are jus dispostivum."); Merlin Magallona, The Concept of Jus Cogens in the Vienna Convention on the Law of the Treaties, 51 PHIL. L.J. 521 (1976) ("jus dispositivum rules which can be derogated by private contracts."); see also Levan Alexidze, The Legal Nature of Jus Cogens in Contemporary International Law, in 172 ReCueIl Des Cours: Collected COURSES OF THE HAGUE ACADEMY OF INTERNATIONAL LAW 245 (1981-III); ALDANA ROHR, LA RESPONSABILIDAD Internacional Del Estado Por Violación Al Jus Cogens 5 (Buenos Aires, 2015) ("por un lado, aquellas de naturaleza dispositive-jus dispositivum-las más numeosasa, creada por aacurdo de voluntades, derogables también por acuerdos de voluntades" ["most of the rules [of international law] have a dispositive character-jus dispostivum-created by an agreement of wills, which can also be derogated by an agreement of wills"]).

20 See Statement of Caflisch in Support of the Draft Conclusion, U.N. GAOR, 68th Sess., 33144th mtg. at 9-10, U.N. Doc. A/CN.4/SR/3314 (July 4, 2016). 
saying and its premise was so basic that it did not require substantial justification. Professor Jalloh, the organizer of this symposium, before he became member of the Commission, when I told him of the push-back I got from some members of the Commission, quipped, "But I thought this was international law 101." 21 Moreover, this basic notion was supported by wealth of State practice and decisions of international courts and tribunals. ${ }^{22}$ Yet some members of the Commission-Wood, Murphy, Nolte, Forteau, Gervogian and Huang-opposed this provision. In the composition of the Commission in 2016, the objections of these few members were sufficient to stall the adoption of this provision by the Drafting Committee. While those members that were opposed to these characteristics were in the minority, they wielded sufficient power and influence to prevent the adoption, even by the Drafting Committee, of the provision. Unlike the provision on the distinction between jus dispositivum and jus cogens this provision was one which I, as Special Rapporteur, was willing to "fall on my sword" for-indeed if the Commission could not adopt this basic rule, I would have resigned as Special Rapporteur. Thus, while I was willing to withdraw the proposal on the distinction between jus cogens and jus dispositivum, these basic characteristics of jus cogens were a red line for me-I could not proceed as Special Rapporteur if the Commission were not willing to accept these characteristics, more so because they were supported by practice. ${ }^{23}$

The following year, 2017, the Commission was reconstituted after an election, and its new composition, not only overwhelmingly supported the provision as a basic tenant of existing law but insisted on its adoption by the Drafting Committee. Given the strong support in practice, the text stating that jus cogens was hierarchically superior to other norms of international law was universally applicable and was a reflection (and protection) of the fundamental values of the international community, was overwhelmingly

21 Quoted with permission from Professor Jalloh.

22 See Prosecutor v. Furundžija, Case No. IT-95-17/1-T, Judgment, 1153 (Int'l Crim. Trib. for the Former Yugoslavia Dec. 10, 1998) (a feature of the prohibition of torture "relates to the hierarchy of rules in the international normative order. . . . this principle has evolved into a peremptory norm or jus cogens, that is, a norm that enjoys a higher rank in the international hierarchy than treaty law and even 'ordinary' customary rules.”); Armed Activities on Territory of Congo (New Application: 2002) (Dem. Rep. Congo v. Rwanda), Judgment, 2006 I.C.J. 6, 10 (Feb. 3) (separate opinion of ad hoc Dugard, J.); see also Arrest Warrant of 11 April 2000 (Dem. Rep. Congo v. Belg.), Judgment, 2002 I.C.J. 3, ๆ 7 (Feb. 14) (dissenting opinion of Al-Khasawneh, J.); Int'l Law Comm'n, Rep. on the Work of Its Sixty-Third and Sixty-Fifth Sessions, U.N. Doc. A/C.6/68/SR.25, ๆ 101 (Dec. 2, 2013) (statement by Mr. Van Den Bogaard (Netherlands): "Jus cogens was hierarchically superior within the international law system, irrespective of whether it took the form of written law or customary law."). But see ROBERT KOLB, PEREMPTORY INTERNATIONAL LAW_JUS COGENS: A GENERAL INVENTORY 37 (2015) (suggesting that the language of hierarchy should be avoided and that the focus should be on voidness since the former concept-of hierarchy-leads to confusion and misunderstanding).

23 Tladi, Second Report, supra note 7, at 10-15. 
adopted by the Drafting Committee with the general support of States. It is hard to describe the contested draft conclusion as anything but codificationcodification in the American tradition of restatement of laws. States, too, overwhelmingly supported these characteristics. ${ }^{24}$ Only a few States did not support the characteristics. ${ }^{25}$

The second report, which focused on the criteria for peremptoriness, did not raise many issues of substance. Many of the comments focused on the drafting proposals, suggesting that the draft conclusions could be streamlined. As with the first report, the draft conclusions were based on practice of States, in particular decisions of national courts, and international jurisprudence. The excitement of the topic jus cogens returned during the consideration of the third report. The third report covered effects or consequences of jus cogens. The report divided the effects of jus cogens into five categories: effects on treaties, effects on other sources of law (customary international law, unilateral declarations and decisions of international organizations), effects on State responsibility, and finally effects on individual criminal responsibility.

On the effects of jus cogens on treaties, the main question concerned dispute settlement. It is this question that I wish to focus on. Should a State be entitled, without the benefit of a third-party dispute settlement procedure, to claim that a treaty was void and thus extricate itself from obligations freely assumed? Those States that had reservations about jus cogens when the Vienna Convention on the Law of Treaties was adopted raised this very issue. They argued that including the provision in the Convention would risk destabilizing treaty relations. The compromise arrived at was the inclusion of Article 66, which provided that the invalidity of a treaty on account of jus cogens was subject to a dispute settlement procedure. ${ }^{26}$ On the one hand, this provision was an essential basis for the inclusion of Article 53 of the Vienna Convention, so that excluding it would be problematic. On the other hand, there was no practice supporting this provision at all; i.e., in all the time of the Vienna Convention, it had never been relied on, not even as an instrument of rhetoric. Courts, both domestic and international, States in their statements before international organizations, and authors in their writings routinely referred to invalidation of treaties (and other rules) as a consequence of $j u s$

24 For a summary of the views of the States on the characteristics proposed by the Special Rapporteur, see Tladi, Second Report, supra note 7, at 6-7, and Tladi, Third Report, supra note 7, at 5-6.

25 States that explicitly rejected these characteristics were China and the United States. See Tladi, Second Report, supra note 7, at 13.

26 Vienna Convention on the Law of Treaties art. 66(a), May 23, 1969, 1155 U.N.T.S. 331 ("Any one of the parties to a dispute concerning the application or the interpretation of article 53 or 64 may, by a written application, submit it to the International Court of Justice for a decision unless the parties by common consent agree to submit the dispute to arbitration" if the dispute is not resolved through amicable procedures). 
cogens, but rarely linked this with dispute settlement procedure. Moreover, many States that were party to the Vienna Convention had entered reservations stating that they do not recognize the application of Article 66. To link the invalidation of the treaty on account of inconsistency with jus cogens to the dispute settlement provisions of Article 66 would thus be going beyond codification and moving into the realm of progressive development and maybe even new law, since there was virtually no practice. The third report therefore proposed, in an effort to be responsive to these factors that pulled in opposite directions, a provision on "recommended practice." This was a clear indication that the provision was not codification and ought to be treated as progressive development.

Members of the Commission were divided. ${ }^{27}$ Others expressed concern that a provision that was clearly mandatory under the Vienna Convention on the Law of Treaties was being downgraded to the status of a recommended procedure which was not binding. Other members, on the other hand, objected that the proposed provision sought to make what was not binding on States that were not party to the Vienna Convention and which, in some cases, had been expressly rejected by even States party to the Vienna Convention, into a rule that was generally binding. Of course, neither of these (extreme) arguments were convincing. In response to those who sought to strengthen the provision, the work of the Commission is aimed at codifying and progressively developing general international law. It is not meant to (and cannot) affect existing treaty regimes applicable between States, save where those treaty regimes are contrary to jus cogens. Thus, it is wrong to suggest that not including the dispute settlement provision in an obligatory language would have the effect of downgrading it for those States that are party to the Vienna Convention. Of course, whatever the Commission's draft conclusions may say (or not say) about dispute settlement, those States that are party to the Vienna Convention, and which have not entered reservations to Article 66, would continue to be bound, as a matter of treaty law, by Article 66 of that Convention. The argument of downgrading was thus a red herring. Those who argued that the proposed provision would make binding a rule that some States had specifically rejected were also overstating the case. The fact is that a provision titled "recommended procedure" and crafted in hortatory language is by definition non-binding, and there was nothing in the proposed draft conclusion that suggested otherwise.

The challenge for the Commission remained to find a balance between preventing unilateral determination of the invalidity of treaties by some States, on the one hand, and on the other hand, preventing a State from insisting on the validity of a treaty that is inconsistent with a norm of jus

27 See Int'1 Law Comm'n, Rep. on the Work of Its Seventieth Session, U.N. Doc. A/73/10, at 231 (2018). 
cogens by withholding consent to third party dispute settlement. Without sufficient practice subsequent to the Vienna Convention, the Drafting Committee relied on the elements of Article 66, as treaty practice, elements of the proposal of the Special Rapporteur and a little common sense, to come up with a text which is, without question, progressive development and which should meet the two competing interests. The text provides for amicable solutions and, in the event that there is no amicable solution, it provides that "the objecting State or States concerned offer to submit the matter to the International Court of Justice," and that "the invoking State may not carry out the measure which it has proposed until the dispute is resolved." ${ }^{28}$ In other words, if the State objecting to the claim that the treaty conflicts with a norm of jus cogens does not offer to submit the matter for settlement by the International Court of Justice, the State invoking the invalidity of the treaty may treat the treaty as invalid on account of conflict of with jus cogens. If, on the other hand, the objecting State offers its consent to the jurisdiction of the Court, the invoking State cannot rely on the invalidity unless there has been a judicial settlement - in other words, a condition for reliance on the invalidity of the treaty is accepting the offer for judicial settlement. The provision, thus, simply provides an incentive on both the objecting and invoking State to seek third party judicial settlement, without suggesting a legal obligation to do so. The provision adopted, to my mind, qualifies as a "progressive development of international law and its codification," i.e., it represents what the Commission has referred to as a "composite idea of codification and progressive development."

The fourth report, which at the time of writing has yet to be debated, has also been based largely on practice. ${ }^{29}$ This fourth report, which covers the question of an illustrative list, however, proceeds from the assumption that the list of examples of norms of jus cogens provided by the Commission in the commentary to the Articles on States Responsibility is accurate. The norms identified by the Commission as examples of jus cogens are the prohibition of aggression, the prohibition of genocide, the prohibition of slavery, the prohibition of crimes against humanity, the prohibition of war crimes, the prohibition of torture, the prohibition of apartheid and racial discrimination, and the right to self-determination. ${ }^{30}$ When the Commission presented the list in 2001, it offered little authority for why, in its view, these norms were jus cogens. The fourth report proceeds from this list, and tests whether the practice of States and decisions of international courts and

28 See Charles Chernor Jalloh (Chairperson of the Drafting Committee), Oral Interim Rep. on Peremptory Norms of General International Law (Jus Cogens), at 15-16 (July 26, 2018).

29 See generally Tladi, Fourth Report, supra note 7.

30 Int'l Law Comm'n, Rep. on the Work of Its Fifty-Third Session, U.N. Doc. A/56/10, at 85 (2008). 
tribunals offer support for the list identified by the Commission. In each case the report concludes that there is ample support in State practice and the jurisprudence of the international courts and tribunals that the norms identified by the Commission in 2011 are accepted and recognized as norms from which no derogation is permitted. What the report does not do, is to assess whether the practice emerged as a result of the list or whether the list was based on existing practice at the time of the adoption of the Articles on States Responsibility. That question, while interesting, is immaterial for the purposes of codification and progressive development. What matters is that it can be shown that, as the law currently exists, the norms identified in the Commission's work in 2001 are norms of jus cogens.

It is unlikely that these norms will raise significant debate within the Commission - although with this Commission, more straightforward things in the realm of international law 101 have been known to be questioned. The real question - or criticism - will be of other norms not listed in the report. In other words, it is expected that some members, and some States, will pose the question of why other norms that arguably meet the criteria for jus cogens have not been included in the list. As Special Rapporteur, in thinking about whether to have an illustrative list, it became apparent that an illustrative list would, necessarily, always be subject to criticism: why this norm and not that one. More importantly, it also became clear that an attempt to draw up a list would fundamentally change the nature of the topic. The topic jus cogenslike the topic identification of customary international law and unlike other topics like crimes against humanity, immunity of State officials, or the protection of the environment in relation to armed conflict - is inherently a methodological topic and not one concerned with the substance of particular rules of international law. An attempt to draw up a list would require delving into the substance of several topics. On the other hand, it was also clear that many "stakeholders" were very interested in an illustrative list, and there would be serious disappointment if the Commission did not provide something approximating a list. I decided on a middle of the road approach. I would propose that the Commission, rather than embark on identifying an illustrative list, confirms the peremptory status of norms it had previously identified as jus cogens. As a second point, the commentary would refer to other norms whose jus cogens status was emerging or whose peremptory status had been championed. This second category of norms would be based on a more superficial study of practice. The norms identified in this category are enforced disappearance, the right to life and non-refoulement. With respect to these norms, the fourth report suggests that there is some evidence of acceptance and recognition of non-derogability, but that the evidence is, as yet, inconclusive. The fourth report also looks at other norms which, though normatively deserving, have not generated the requisite support in the form of practice. 
In its work on the topic jus cogens the Commission, and its attempt to stay true to its commitment of progressive development and codification, has often had to make decisions between consistency with the Vienna Convention and, on the other hand, reflecting current practice. Sometimes, the Commission - or rather the Drafting Committee, since the Commission has yet to adopt any text- - has decided to "depart" from the text of the Vienna Convention and follow more closely the practice. This was the case with the characteristics. The Vienna Convention does not mention "hierarchical superiority," "universal applicability," or "fundamental values." Although these characteristics are not included in the Vienna Convention, they are not inconsistent with it. They have emerged from the implementation and application of Article 53 and have become part of the fabric of the definition of jus cogens. At other times, the Drafting Committee has opted to stick, religiously, to the text of the Vienna Convention. The compromise text on the dispute settlement procedure is an example of the Drafting Committee creatively using the text of the Convention, while allowing practice to dictate what it includes and does not include.

\section{CONCLUSION}

The mandate of the Commission is the progressive development and codification of international law as a composite act. This composite act should always be based on State practice, the decisions of international courts and tribunals and underpinned by solid doctrine. The work of the Commission on jus cogens thus far completed has managed to keep the balance. Yet the Commission has faced two mutually defeating criticisms. On the one hand, a number of States-France, the United States, Turkey, the Czech Republic, Israel and a few others-have suggested, without substantiation, that the work on this topic has far thus been based on theory and doctrine and not practice. The fourth report, in refuting this attack made the following observations:

It is difficult to respond to the criticism that the work of the Special Rapporteur and the Commission have followed a theoretical approach and have not relied on practice since none of the States have pointed to a single draft conclusion not supported by some practice. Although only a small minority of States made this allegation, it is so serious and damning that, exceptionally, some example to refute it are necessary. State Practice in the form of national judicial decisions, statements by States, treaty practice, resolutions of the General Assembly, and resolutions of the Security Council is provided in the report in abundance. The report is 
also replete with invocations of international and regional jurisprudence. $^{31}$

Yet another completely contradictory criticism has been that the work of the Commission has not paid sufficient attention to theory and doctrine. One member of the Commission, and former Chair, has been the leading proponent of this line of attack. In the introduction of the first report, I alluded to Pellet's clever reference to the initials of jus cogens being the same as someone who once turned water into wine. In his comment on the report, Valencia-Ospina picked up on this reference and suggested that by sticking to what had been said in case law, legislation, and the Vienna Convention, and by not exploring the theoretical complexities of jus cogens, the project would offer "more water than wine." This criticism has been repeated methodically each year without fail by Valencia-Ospina.

These criticisms confirm, at least to me, that the project is on the right track. At the very beginning, the first report emphasized that the object of the project was not to resolve theoretical debates - interesting though they may be. ${ }^{32}$ Rather, the objective would be to try to identify the existing law on jus cogens and to offer to States a proposal for progressive development and codification of international law on jus cogens by a careful, dispassionate assessment of practice. The accurate criticism that the work has paid too much attention to practice and not enough to theory does two things. First, it dispels the criticism of the few States that the work on the topic is based on theory and doctrine. Second, it confirms that the Commission has managed to strike the right balance in its composite mandate of progressive development of international law and its codification. We are not here to turn water into wine. We are merely here to purify the water, so that it may be potable.

31 Tladi, Fourth Report, supra note 7, 920 (footnotes omitted).

32 Tladi, First Report, supra note 7, at 6. 